\title{
Preparation and Characterisation of Protein Hydrolysates from Indian Defatted Rice Bran Meal
}

\author{
Kakali Bandyopadhyay ${ }^{1}$, Gautam Misra ${ }^{2}$ and Santinath Ghosh ${ }^{2 *}$ \\ ${ }^{1}$ Guru Nanak Institute of Technology (157/F Nilgang Road Kolkata 700-114, INDIA) \\ ${ }^{2}$ Department of Chemical Technology, Oil Technology Division, University of Calcutta (92, Acharya Prafulla Chandra Road, Kolkata-700-009, \\ West Bengal, INDIA)
}

\begin{abstract}
Rice bran meal is a very good source of protein along with other micronutrients. Rice bran meal has been utilized to produce protein isolates and respective protein hydrolysates for potential application in various food products. De-oiled rice bran meal, available from Indian rice bran oil extraction plants, was initially screened by passing through an 80-mesh sieve (yield about 70\%). A fraction (yield-30\%) rich in fibre and silica was initially discarded from the meal. The protein content of the through fraction increased from $20.8 \%$ to $24.1 \%$ whereas silica content reduced from $3.1 \%$ to $0.4 \%$. Rice bran protein isolate (RPI) was prepared by alkaline extraction followed by acidic precipitation at isoelectric point. This protein isolate was hydrolysed by papain at $\mathrm{pH} 8.0$ and at $37^{\circ} \mathrm{C}$ for $10,20,30,45$ and 60 minutes. The peptides produced by partial hydrolysis had been evaluated by determining protein solubility, emulsion activity index (EAI), emulsion stability index (ESI), foam capacity and foam stability (FS). All protein hydrolysates showed better functional properties than the original protein isolate. These improved functional properties of rice bran protein hydrolysates would make it useful for various application especially in food, pharmaceutical and related industries.
\end{abstract}

Key words: functional properties, papain, protein hydrolysates, rice bran meal

\section{INTRODUCTION}

Rice bran, one important oil bearing material with 12$20 \%$ protein content, may be a potential source of inexpensive high quality protein for new food uses ${ }^{1)}$. Protein has been extracted from rice bran for various food and pharmaceutical applications $^{2-6)}$. Rice bran protein has been used as hypoallergenic milk replacers in infant formulas ${ }^{4}$. Relatively pure rice bran protein can be produced by alkaline extraction followed by precipitation of protein by adjusting the $\mathrm{pH}$ to its isoelectric point. But the procedure for extracting protein from rice bran must be carefully selected to produce protein isolates or concentrates with desirable functional properties ${ }^{5)}$. Tang et $a l^{7)}$ extracted protein from heat stabilised defatted rice bran by physical processing followed by enzyme treatment. They reported that physical processing (high pressure, sonication or blending) in combination with amylase or protease treatment extracted about $66 \%$ protein from defatted rice bran.

Proteolytic enzyme modification of proteins is an effective way to improve the various functional properties and to increase the field of application of the proteins ${ }^{8-10)}$. The peptides that are produced by partial hydrolysis of proteins have smaller molecular size and less secondary structure than the original proteins. The protein solubility, emulsifying properties and foaming properties can be improved with a limited degree of hydrolysis ${ }^{11-13)}$, whereas excessive hydrolysis often causes loss of some of these functionalities $^{14)}$. Protein hydrolysates are widely used as nutritional supplements, functional ingredients and flavour enhancers in foods, coffee whiteners, cosmetics, personal care products, and confectionery, and in the fortification of soft drinks and juices. Protein hydrolysates are also used in soups, sauces, gravies, snacks, meat products and other savoury applications ${ }^{15-16)}$.

*Correspondence to: Santinath Ghosh, Department of Chemical Technology, Oil Technology Division, University of Calcutta, 92 A.P.C. Road, Kolkata-700 009, West Bengal, INDIA

E-mail: santinathghosh@yahoo.com.hk

Accepted September 22, 2007 (received for review August 29, 2007)

Journal of Oleo Science ISSN 1345-8957 print / ISSN 1347-3352 online

http://jos.jstage.jst.go.jp/en/ 
In the present study, protein isolate was produced from defatted rice bran meal available in India. Protein hydrolysates, with variable degree of hydrolysis, were prepared from protein isolate by papain and characterized by their functional properties to determine the potential application of these hydrolysates in various food products.

\section{MATERIALS AND METHODS}

\subsection{Sample collection}

Full-fat rice bran was obtained from Sethia Oils Ltd. (Burdwan, W.B., India). The de-oiled bran (meal) was prepared by solvent extraction in a soxhlet apparatus using hexane (food grade). After complete extraction the meal was desolventized in a vacuum oven at $60^{\circ} \mathrm{C}$ and $4 \mathrm{~mm} \mathrm{Hg}$ for $4 \mathrm{~h}$. The de-oiled meals were stored in desiccators and used for further experiment.

\subsection{Sieving of rice bran meal}

Rice bran meal was screened to pass through an 80mesh (1770- $\mu$ m openings) sieve. The fraction (through fraction), passing through the sieve was used as starting material for further study. Papain from papaya latex, having activity 100TU (6000NF) was purchased from Loba Chemie Pvt. Ltd., Mumbai, India, and was used for hydrolysis.

\subsection{Preparation of rice bran protein isolate}

Rice bran meal (through fraction) was mixed thoroughly with 10 times distilled water, $\mathrm{pH}$ of the medium was then adjusted to 10.0 and was stirred for $1 \mathrm{~h}$ at $50-55^{\circ} \mathrm{C}$. The slurry was centrifuged at $4000 \times \mathrm{g}$ for $10 \mathrm{~min}$. The $\mathrm{pH}$ of the supernatant liquid was further adjusted to 4.0 with $1 \mathrm{~N}$ $\mathrm{HCl}$ and again stirred for $1 \mathrm{~h}$ at $50-55^{\circ} \mathrm{C}$, centrifuged at $8000 \times \mathrm{g}$ for $20 \mathrm{~min}$. The solid residue (rice bran protein isolate, RPI) thus obtained was collected and dried in a vacuum oven at $50^{\circ} \mathrm{C}$ for $10 \mathrm{~h}$.

\subsection{Preparation of protein hydrolysates by papain}

Five $10 \mathrm{~g}$ portions of respective rice bran protein isolates (RPI) were each dispersed in $200 \mathrm{ml}$ of distilled water, adjusted to pH10.0 with $1.0 \mathrm{~N} \mathrm{NaOH}$, and incubated at $50^{\circ} \mathrm{C}$ for $1 \mathrm{~h}$ with shaking. Each portion were then adjusted to $\mathrm{pH} 8.0$ and hydrolyzed with $0.1 \%(\mathrm{w} / \mathrm{w})$ papain. The hydrolysis was carried out at $37^{\circ} \mathrm{C}$ for $10,20,30,45$ and 60 min with constant shaking. The resulting hydrolysates (RPH10, RPH20, RPH30, RPH45 and RPH60 respectively) were adjusted to pH8.0 and the enzymes were rapidly inactivated by heating at $95^{\circ} \mathrm{C}$ for $5 \mathrm{~min}$. The hydrolysates were then freeze-dried and stored at $4^{\circ} \mathrm{C}$ for further studies.

Total nitrogen was determined according to the Kjeldahl method. Crude protein content was estimated using a conversion factor of 6.25. Moisture, ash, crude fiber content, protein dispersibility index (PDI), and nitrogen solubility index (NSI) were determined by using Official and Tentative Methods of $\mathrm{AOCS}^{17}$. Silica content was determined by converting about $1 \mathrm{~g}$ of sample into ash in a muffle furnace at $700^{\circ} \mathrm{C}$. Then the ash was taken in a platinum crucible and about $10 \mathrm{ml}$ hydrofluoric acid was added and boiled gently in a heater with asbestos gauze. Gradually silica was removed by converting into volatile fluorosilicic acid. After complete volatilization the crucible was strongly heated directly in the heater for $5 \mathrm{~min}$, the crucible was cooled in a desiccator and weighed. The silica content was calculated from the loss of the weight.

\subsection{Determination of protein solubility}

To determine protein solubility at different $\mathrm{pH}, 20 \mathrm{mg}$ of each protein sample was dispersed in $20 \mathrm{ml}$ deionized water, adjusted to $\mathrm{pH} 3,5,7$ and 9 with $0.1 \mathrm{~N} \mathrm{HCl}$ or $0.1 \mathrm{~N}$ $\mathrm{NaOH}$, magnetically stirred at ambient temperature for 30 min, and centrifuged at $12100 \times \mathrm{g}$ for $10 \mathrm{~min}$. Protein contents were determined by the Lowry et $a .^{18}{ }^{18}$. Method of protein assay with protein isolate as standard for which the protein content was determined by the Kjeldahl method $^{17}$. Protein solubility was calculated as:

Solubility $(\%)=($ protein content in supernatant $) /($ protein content in sample $) \times 100$.

\subsection{Determination of emulsifying properties}

Emulsifying properties were measured by the method of Pearce and Kinsella ${ }^{19}$. Pure corn oil (2 ml) and $6 \mathrm{ml}$ of $0.1 \%$ protein solution ( $\mathrm{pH}-8.0$ ) were homogenized in a mechanical homogenizer at the highest setting for $1 \mathrm{~min} .50 \mu \mathrm{L}$ portion of the emulsions were pipetted from the bottom of the container at 0 and $10 \mathrm{~min}$ after homogenization. Each portion was diluted with $5 \mathrm{ml}$ of $0.1 \%$ SDS (sodium dodecyl sulphate) solution. Absorbance of these diluted solutions was measured at $500 \mathrm{~nm}$ with the aid of UV-VIS-Spectrophotometer (UV1601, SHIMADZU, Japan) against the appropriate blank. The absorbance measured immediately (A0) and 10 min (A10) after emulsion formation were used to calculate emulsifying activity index (EAI) and the emulsion stability index $(\mathrm{ESI}) . \mathrm{EAI}\left(\mathrm{m}^{2} / \mathrm{g}\right)=2 \mathrm{~T}[(\mathrm{~A} 0 \times$ dilution factor $/(\mathrm{c} \times \phi \times 10,000)]$ where $\mathrm{T}=2.303$, dilution factor $=$ $100, \phi=$ oil volume fraction of emulsion, $\mathrm{c}=$ weight of protein per unit volume of aqueous phase before the emulsion is formed.

$\mathrm{ESI}(\min )=\mathrm{A} 0 \times \Delta \mathrm{t} / \Delta \mathrm{A}$, where $\Delta \mathrm{t}=10 \min$ and $\Delta \mathrm{A}=\mathrm{A} 0-\mathrm{A} 10$

\subsection{Determination of foaming properties}

Foaming properties in terms of foam capacity $(\mathrm{FC})$ and foam stability (FS) were determined by the method of Okezie and Bello ${ }^{20}$. It was expressed as percentage volume increase and calculated as shown below:

$\mathrm{FC}=$ (volume after whipping-volume before whipping)/ volume before whipping $\times 100$. 
FS was determined by measuring the foam height at 10,30, 45 and 60 minutes. Both the FC and FS were determined at $\mathrm{pH} 8.0$ and at room temperature $\left(31 \pm 2^{\circ} \mathrm{C}\right)$.

\subsection{Determination of degree of hydrolysis}

Degree of hydrolysis, defined as the percentage of peptide bonds cleaved, was calculated by the determination of free amino groups by reaction with 2,4,6-trinitrobenzene sulphonic acid (TNBS) (Sigma Chemical Co., St. Louis, MO) according to the method of Alder-Nissen ${ }^{21}$. $0.250 \mathrm{ml}$ of a sample containing between $0.25 \times 10^{-3}$ and $2.5 \times 10^{-3}$ amino equiv/L, is mixed in a test tube with $2.0 \mathrm{ml}$ of phosphate buffer at pH8.2. $2 \mathrm{ml}$ of $0.1 \%$ TNBS solution was added and the test tube was shaken and placed in a water bath at 50 $\pm 1^{\circ} \mathrm{C}$ for $60 \mathrm{~min}$. During incubation the test tubes and the water bath must be covered with aluminium foil because the blank reaction is accelerated by exposure to light. After $60 \mathrm{~min} 4.0 \mathrm{ml}$ of $0.1(\mathrm{~N}) \mathrm{HCl}$ was added to terminate the reaction, and the test tube was allowed to stand at room temperature for 30 min before the absorbance was read against water at $340 \mathrm{~nm}$.

The total number of amino acid groups was determined in a $100 \%$ hydrolyzed sample at $110^{\circ} \mathrm{C}$ for $24 \mathrm{~h}$ in $6(\mathrm{~N}) \mathrm{HCl}$ (10 $\mathrm{mg}$ of sample in $4 \mathrm{ml}$ of $\mathrm{HCl}$ ).

\section{RESULTS AND DISCUSSION}

The proximate composition of deoiled Indian rice bran meal and its two different fractions were shown in Table 1. Commercial rice brans in India were contaminated with rice husk during milling. To reduce the fibre, ash and silica, the rice bran meals were screened by 80 -mesh sieve. A fraction (over fraction, yield 30\%) rich in crude fibre, silica and ash was discarded. In the through fraction, the protein content increased from 20.8 to $24.1 \%$, fibre content reduced from $16.7 \%$ to $13.9 \%$ and silica content was reduced from 3.1 to $0.4 \%$. The quality of protein in terms of PDI and NSI
Table 2 Characteristics of Rice Bran Protein Isolate Obtained from Through Fraction of Rice Bran Meal.

\begin{tabular}{cr}
\hline Properties & Composition \\
\hline Protein (\%) & $86.2 \pm 1.1$ \\
Crude fiber (\%) & $1.8 \pm 0.2$ \\
Ash (\%) & $0.3 \pm 0.1$ \\
Silica (\%) & $0.03 \pm 0.01$ \\
\hline
\end{tabular}

Values are mean \pm s.d., $\mathrm{n}=3$

values was also improved in through fraction. So, screening was essential to improve its quality in terms of protein content and solubility. This through fraction was used as starting material for further study.

Rice bran protein isolate (RPI) was produced from the through fraction. The chemical analysis of RPI were given in Table 2. Different undesirable components like crude fibre, ash and silica contents were very low in this protein isolate. Due to very high protein content, RPI fraction could be utilized in various food and pharmaceutical formulations.

Rice bran protein isolate was hydrolyzed with papain at $0.1 \%$ level and the entire product mixture was freeze dried to produce protein hydrolysate. Due to presence of $0.1 \%$ papain in the reaction mixture, its effect on the physical properties of the protein hydrolysates was negligible. Solubility of rice bran protein hydrolysates (prepared by using papain) at $\mathrm{pH}$ 3.0, 5.0, 7.0 and 9.0 from rice bran protein isolate was presented in Table 3. After hydrolysis the protein solubility at $\mathrm{pH} 7.0$ was increased from $79.6 \%$ for control RPI to 83.6, 84.7, 86.2, 86.6 and 87.0\% for RPH10, RPH20, $\mathrm{RPH} 30, \mathrm{RPH} 45$ and RPH60 respectively. The increased protein solubility could be due to smaller molecular peptides being produced by papain hydrolysis. Unfolding of protein molecule due to hydrolysis was also of the reason for its improved solubility. Improvement of protein solubility due

Table 1 Characteristics of Deoiled Rice Bran Meal and Its Two Different Fractions Obtained by Sieving.

\begin{tabular}{cccr}
\hline Characteristics & Deoiled rice bran & Through fraction & Over fraction \\
\hline Moisture (\%) & $10.3 \pm 0.9$ & $11.0 \pm 0.8$ & $8.6 \pm 0.4$ \\
Protein (\%) & $20.8 \pm 0.8$ & $24.1 \pm 1.0$ & $13.1 \pm 0.8$ \\
Crude fiber (\%) & $16.7 \pm 0.6$ & $13.9 \pm 0.8$ & $23.2 \pm 0.7$ \\
Ash (\%) & $14.9 \pm 0.9$ & $11.3 \pm 0.8$ & $21.8 \pm 0.8$ \\
Silica (\%) & $3.1 \pm 0.3$ & $0.4 \pm 0.1$ & $9.3 \pm 0.6$ \\
NSI & $19.6 \pm 0.9$ & $29.9 \pm 0.7$ & $17.1 \pm 0.7$ \\
PDI & $30.0 \pm 0.8$ & $44.0 \pm 1.0$ & $29.0 \pm 0.8$ \\
\hline
\end{tabular}

NSI: Nitrogen solubility index PDI: Protein dispersability index

Values are mean \pm s.d., $\mathrm{n}=3$ 
Table 3 Solubility of Rice Bran Protein Isolate (RPI) and Different Protein Hydrolysates (RPH10, RPH20, RPH30, RPH45 \& RPH60) Prepared by Using Papain.

\begin{tabular}{ccccc}
\hline \multirow{2}{*}{ Products } & \multicolumn{4}{c}{ Solubility $(\%)$ at different $\mathrm{pH}$} \\
\cline { 2 - 5 } & 9.0 & 7.0 & 5.0 & 3.0 \\
\hline RPI & $84.5 \pm 0.9$ & $79.6 \pm 0.8$ & $54.1 \pm 0.7$ & $28.5 \pm 0.6$ \\
RPH10 & $86.3 \pm 0.8$ & $83.6 \pm 0.8$ & $59.6 \pm 0.9$ & $29.8 \pm 0.7$ \\
RPH20 & $86.9 \pm 1.1$ & $84.7 \pm 0.9$ & $60.1 \pm 0.8$ & $33.4 \pm 0.5$ \\
RPH30 & $91.6 \pm 0.9$ & $86.2 \pm 0.9$ & $60.3 \pm 0.7$ & $39.1 \pm 0.7$ \\
RPH45 & $91.7 \pm 1.0$ & $86.6 \pm 0.8$ & $61.1 \pm 0.8$ & $44.4 \pm 0.6$ \\
RPH60 & $94.8 \pm 0.8$ & $87.0 \pm 0.7$ & $61.5 \pm 0.9$ & $44.9 \pm 0.6$ \\
\hline
\end{tabular}

RPI : Rice bran protein isolate RPH10, RPH20, PRH30, RPH45, RPH60 are the rice bran protein hydrolysates produced at $10,20,30,45$ and $60 \mathrm{~min}$ hydrolysis respectively

Values are mean \pm s.d., $n=3$

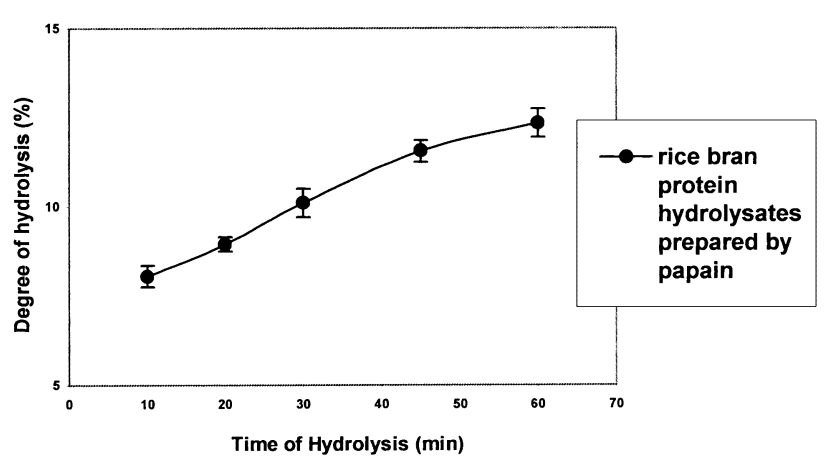

Fig. 1 Degree of Hydrolysis of Rice Bran Protein Hydrolysates (RPH10-RPH60) Prepared by Papain.

Table 4 Emulsifying properties of Rice Bran Protein Isolate (RPI) and Different Protein Hydrolysates (RPH10, RPH20, RPH30, RPH45 \& RPH60) Prepared by Papain.

\begin{tabular}{ccc}
\hline Products & EAI $\left(\mathrm{m}^{2} / \mathrm{g}\right)$ & ESI $(\mathrm{min})$ \\
\hline RPI & $108.9 \pm 0.8$ & $36.9 \pm 0.7$ \\
RPH10 & $149.6 \pm 0.9$ & $46.9 \pm 0.6$ \\
RPH20 & $150.8 \pm 0.7$ & $47.3 \pm 0.8$ \\
RPH30 & $156.9 \pm 0.8$ & $45.9 \pm 0.7$ \\
RPH45 & $167.1 \pm 0.9$ & $46.9 \pm 0.9$ \\
RPH60 & $185.4 \pm 1.1$ & $48.0 \pm 0.8$ \\
\hline
\end{tabular}

Values are mean \pm s.d., $n=3$

EAI-Emulsion activity index, ESI-Emulsion stability index to enzymatic hydrolysis of sesame protein was reported in our previous publication ${ }^{22)}$.

The degree of hydrolysis of different rice bran protein hydrolysates was given in Fig. 1. The degree of hydrolysis was measured by determining the free amino groups present in the mixture. The degree of hydrolysis increased steadily from $10 \mathrm{~min}$ to $60 \mathrm{~min}$ time period. The solubility of the protein hydrolysate also increased with the time of hydrolysis due to cleavage of the peptide bonds. The hydrolysis reaction was continued for 60 min just to get the peptides of reasonable size for optimum functional properties. Though the size of the peptides cannot be correlated with the degree of hydrolysis.

From Table 4 it was found that papain modification significantly improved the EAI of RPI from $108.9 \mathrm{~m}^{2} / \mathrm{g}$ to 149.6, 150.8, 156.9, 167.1 and $185.4 \mathrm{~m}^{2} / \mathrm{g}$ for $\mathrm{RPH}_{10}, \mathrm{RPH}_{20}$, $\mathrm{RPH}_{30}, \mathrm{RPH}_{45}$ and $\mathrm{RPH}_{60}$ respectively. The EAI is mainly dependent on the diffusion of peptides at oil-water interfaces. Hydrolysates with high solubility and smaller molecular size should facilitate that diffusion and enhance the interaction between protein and lipid. Papain modification also significantly increased the ESI of RPI from 36.9 to 48.0 min for $\mathrm{RPH}_{60}$.

Differences in foaming capacities (FC) among the samples were readily apparent from Table 5 . Foam capacities were increased from 70.0 to 117.6, 120.2, 133.4, 140.6 and $151.2 \%$ volume increase for $\mathrm{RPH}_{10}, \mathrm{RPH}_{20}, \mathrm{RPH}_{30}, \mathrm{RPH}_{45}$ and $\mathrm{RPH}_{60}$ respectively. Hydrolyzed samples showed increased foam capacity over the controlled RPI, showed decreased foam stability. The trend of increased FC and decreased FS caused by enzymatic modification has also been reported by others ${ }^{23}$. Here also like sesame protein hydrolysates the foam stability (FS) decreased with the increase in time of hydrolysis. 
Table 5 Foaming Properties of Rice Bran Protein Isolate (RPI) and Different Protein Hydrolysates (RPH10, RPH20, RPH30, RPH45 \& RPH60) Prepared by Papain at pH8.0.

\begin{tabular}{|c|c|c|c|c|c|c|c|}
\hline \multirow{2}{*}{ Products } & \multirow{2}{*}{$\begin{array}{c}\text { Volume } \\
\text { before } \\
\text { whipping (ml) }\end{array}$} & \multirow{2}{*}{$\begin{array}{l}\text { Volume after } \\
\text { whipping (ml) }\end{array}$} & \multirow{2}{*}{$\begin{array}{c}\text { Foam capacity } \\
(\%)\end{array}$} & \multicolumn{4}{|c|}{ Foam stability (FS), Volume ( $\mathrm{ml}$ ) at room temp. after different time } \\
\hline & & & & $10 \mathrm{~min}$ & $30 \mathrm{~min}$ & $45 \mathrm{~min}$ & $60 \mathrm{~min}$ \\
\hline RPI & 50.0 & $85.0 \pm 0.8$ & $70.0 \pm 0.7$ & $71.0 \pm 0.4$ & $65.0 \pm 0.7$ & $59.0 \pm 0.6$ & $56.0 \pm 0.4$ \\
\hline RPH10 & 50.0 & $108.8 \pm 0.9$ & $117.6 \pm 0.9$ & $68.0 \pm 0.5$ & $60.0 \pm 0.6$ & $57.0 \pm 0.6$ & $54.0 \pm 0.5$ \\
\hline RPH20 & 50.0 & $110.1 \pm 1.1$ & $120.2 \pm 1.2$ & $67.0 \pm 0.6$ & $60.0 \pm 0.8$ & $58.0 \pm 0.7$ & $54.0 \pm 0.6$ \\
\hline RPH30 & 50.0 & $116.7 \pm 1.0$ & $133.4 \pm 1.1$ & $65.0 \pm 0.8$ & $59.0 \pm 0.5$ & $57.0 \pm 0.5$ & $53.0 \pm 0.5$ \\
\hline RPH45 & 50.0 & $120.3 \pm 1.2$ & $140.6 \pm 1.0$ & $63.0 \pm 0.7$ & $57.0 \pm 0.4$ & $55.0 \pm 0.9$ & $52.0 \pm 0.7$ \\
\hline RPH60 & 50.0 & $125.6 \pm 1.1$ & $151.2 \pm 0.8$ & $60.0 \pm 0.6$ & $55.0 \pm 0.8$ & $53.0 \pm 0.6$ & $52.0 \pm 0.8$ \\
\hline
\end{tabular}

Values are mean \pm s.d., $n=3$

\section{CONCLUSION}

Rice bran protein peptides produced by papain modification have high protein solubility and emulsifying property. As papain is the least expensive and FDA-approved vegetable-derived enzyme, the high-value protein hydrolysates prepared by papain can be used as value added ingredients in many food formulations. They are also suitable for a broad range of industrial food applications and also for cosmetic and personal care products.

\section{References}

1. Saunders, R.M. The properties of rice bran as a foodstuff. Cereal Foods World 35, 632-636 (1990).

2. Anderson, A.K.; Guraya, H.S. Extractibility of protein in physically processed rice bran. J. Am. Oil Chem. Soc. 78, 969-972 (2001).

3. Ansharullah, J.; Hourigan, A.; Chesterman, C.F. Application of carbohydrases in extracting protein from rice bran. J. Sci. Food Agric. 74, 141-146 (1997).

4. Landers, P.S.; Hamaker, B.R. Antigenic properties of albumin, globulin, and concentrate fractions from rice bran. Cereal Chem. 71, 409-411 (1994).

5. Hamada, J.S. Characterization of protein fractions of rice bran to devise effective methods of protein solubilization. Cereal Chem. 74, 662-668 (1997).

6. Hamada, J.S. Characteristics of functional properties of rice bran proteins modified by commercial exoproteases and endoproteases. J. Food Sci. 65, 305-309 (2000).

7. Tang, S.; Hettiarachchy, N. S.; Shellhammer, T. H. Protein extraction from heat-stabilized defatted rice bran $: 1$. Physical processing and enzyme treatment. $J$. Agric. Food Chem. 50, 7444-7448 (2002).

8. Panyam, D.; Kilara, A. Enhancing the functionality of food proteins by enzymatic modification. Trends Food
Sci. Technol. 7, 120-125 (1996).

9. Vioque, J.; Sanchez-Vioque, R.; Clemente, A.; Pedroche, J.; MILLAN, F. Partial hydrolyzed rape seed protein isolates with improved functional properties. $J$. Am. Oil Chem. Soc. 77, 447-450 (2000).

10. Wu, W.U.; Hettiarachchy, N.S.; Qi, M. Hydrophobicity, solubility, and emulsifying properties of soy protein peptides prepared by papain modification and ultrafiltration. J. Am. Oil Chem. Soc. 75, 845-850 (1998).

11. Chobert, J.M., Bertrand-Harb, C.; Nicolas, M.G. Solubility and emulsifying properties of caseins and whey proteins modified enzymatically by trypsin. J. Agric. Food Chem. 36, 883-892 (1988).

12. Kim, S.Y.; Park, P.S.W.; Rhee, K.C. Functional properties of proteolytic enzyme modified soy protein isolate. J.Agric. Food Chem. 38, 651-656 (1990).

13. Villaneuva, A.; Vioque, J.; Sanchez-Vioque, R.; Clemente, A.; Pedroche, J.; Bautista, J.; Millan, F. Peptide characteristics of sunflower protein hydrolysates. J .Am. Oil Chem. Soc. 76, 1455-1460 (1999).

14. Kuehler, C.A.; Stine, C.M. Effect of enzymatic hydrolysis on some functional properties of whey protein. $J$. Food Sci. 39, 379-382 (1974).

15. Giese, J. Proteins as ingredients: Types, functions, applications. Food Technol. 48, 50-60 (1994).

16. Weir, G.S.D. Protein hydrolysates as flavourings in development in food protein (Hudson, B.J.F., ed.). Elsevier. London, U.K. pp. 175-217 (1986).

17. Official Methods and Recommended Practices of the American Oil Chemists' Society, 4th ed., A.O.C.S. Champaign, IL, Methods Bc 5-49 (for ash), Ba 6-84 (fiber), Aa 5-91 (nitrogen), Ba 11-65 (NSI) (1991).

18. Lowry, O.; Rosebrough, N.J.; Farr, A.L.; Randall, R.J. Protein measurement with folin-phenol reagent. $J$. Biol. Chem. 193, 265 (1951).

19. Pearce, K.N.; Kinsella, J.E. Emulsifying properties of proteins: Evaluation of a turbidimetric technique. $J$. 
Agric. Food Chem. 26, 716-723 (1979).

20. Okezie, B.O.; Bello, A.B. Physicochemical and functional properties of winged bean flour and isolate compared with soy isolate. J. Food Sci. 53, 450-455 (1988).

21. Alder-Nissen, J. Determination of degree of hydrolysis of food protein hydrolysates by trinitrobenzene sulphonic acid. J. Agric. Food Chem. 27, 1256-1262 (1979).

22. Bandyopadhyay, K.; Ghosh, S. Preparation and charac- terization of papain modified sesame (Sesame indicum L.) protein isolates. J. Agric. Food Chem. 50, 6854-6857 (2002).

23. Bobalic, J.M.; Toranto, M.V. The effect of enzymatic modification of the foaming, water absorption and baking quality of defatted soyflower. J. Food Technol. 15, 637-646 (1980). 